\title{
Evaluation of arterial digital blood flow in dairy cows with claw horn disruption lesions using Doppler ultrasonography
}

\author{
H. Müller, ${ }^{1 *}$ M. Heinrich, ${ }^{1}$ N. Mielenz, ${ }^{2}$ S. Reese,${ }^{3}$ A. Steiner, ${ }^{4}$ and A. Starke ${ }^{1}$ \\ ${ }^{1}$ Clinic for Ruminants and Swine, Faculty of Veterinary Medicine, University of Leipzig, An den Tierkliniken 11, 04103 Leipzig, Germany \\ ${ }^{2}$ Institute for Agriculture and Nutrition, Biometrics and Informatics in Agriculture Group, Martin-Luther-University, \\ Karl-Freiherr-von-Fritsch-Straße 4, 06120 Halle (Saale), Germany \\ ${ }^{3}$ Institute of Anatomy, Histology, and Embryology, Department of Veterinary Sciences, Faculty of Veterinary Medicine, \\ Ludwig Maximilian University of Munich, Veterinaerstraße 13, 80539 Munich, Germany \\ ${ }^{4}$ Clinic for Ruminants, Vetsuisse-Faculty, University of Bern, Bremgartenstrasse 109a, 3012 Bern, Switzerland
}

\section{ABSTRACT}

Vascular changes play an important role in the pathogenesis of claw horn disruption lesions in cattle. The aim of the study was to measure arterial blood flow in the hind limbs of German Holstein cows with claw horn disruption lesions. A $10-\mathrm{MHz}$ linear transducer was used to assess blood flow in the interdigital artery in the dorsal pastern region in the hind limbs of 11 nonlame and 33 lame German Holstein cows in which lameness was scored clinically. Qualitative and quantitative blood flow parameters were compared in affected limbs and unaffected contralateral hind limbs in lame cows and in the hind limbs of lame cows and non-lame cows. A pulsed-wave Doppler signal suitable for analysis was obtained in 78 of 88 limbs (33 affected and contralateral limbs, 22 limbs of control cows). Blood flow curve types 1 and 2 were predominant in the hind limbs of lame cows. Vessel diameter, end-diastolic velocity, and blood flow rate were significantly greater in lame cows than in non-lame cows and were numerically greater in moderately lame cows than in mildly lame cows. The differences in the qualitative and quantitative parameters between lame and non-lame cows were most likely caused by inflammation of the pododerm. The role of weight distribution between the paired hind limbs and the existence of claw horn disruption appeared to have an effect on the differences in local circulation in the affected and unaffected contralateral hind limbs in lame cows.

Key words: lameness, claw horn disruption, pulsedwave Doppler, digital perfusion

Received October 19, 2018.

Accepted May 14, 2019.

*Corresponding author: hendrik.mueller@vetmed.uni-leipzig.de

\section{INTRODUCTION}

Diseases of the locomotor system are of major importance in dairy cattle, and foot lesions are the cause of almost $90 \%$ of lameness (Shearer et al., 2012). Claw horn lesions resulting from underlying dermal abnormalities including sole ulcer and white line abscess are among the most common foot disorders with prevalence ranging from 3 to $17 \%$ in studies from the United States, United Kingdom, Germany, the Netherlands, Switzerland, Norway, and Sweden (Manske et al., 2002; Sogstad et al., 2005; Laven and Lawrence, 2006; Holzhauer et al., 2008; DeFrain et al., 2013; Gernand et al., 2013; Becker et al., 2014). The etiology of these types of foot lesions is multifactorial and includes inadequate barn floor and cubicle surfaces (Hultgren and Bergsten, 2001; De Vries et al., 2015; Solano et al., 2015), abnormal standing and lying times (Proudfoot et al., 2010; Beer et al., 2016), and factors relating to claw trimming (Bell, 2015). Furthermore, anatomical changes including overgrowth of the lateral hind claws (Gonzalez-Sangues and Shearer, 2002; Rüegsegger et al., 2015), exostoses at the flexor tubercle (Newsome et al., 2016), and inadequate absorption of pressure by the digital cushion (Toholj et al., 2014) favor the development of claw horn disruption lesions. Ruminal acidosis and endotoxemia have also been implicated in the pathogenesis of claw horn disruption lesions (Hoblet and Weiss, 2001). Periparturient hormonal changes have been shown to reduce the synthesis and degradation of collagen fibers (Hendry et al., 1997; Tarlton and Webster, 2002), and deficiencies in certain nutritional factors that have an effect on keratinization and cornification of keratinocytes are believed to predispose cattle to claw horn disruption lesions (Mülling et al., 1999). There are 3 phases in the pathogenesis of sole ulcers. Phase 1 involves circulatory disturbances and dysfunction caused by the factors mentioned above, which lead to tissue hypoxia, edema formation, and activation of matrix-metalloproteinases. The result is degrada- 
tion of collagen with variable degrees of failure of the suspensory apparatus. Phase 2 involves sinking of the 3rd phalanx, which causes compression of the dermis. This in turn results in abnormal cell proliferation and differentiation depending on the degree of nutritional undersupply of the dermis. Phase 3 is associated with the appearance of hemorrhages and full-thickness horn defects (van Amstel and Shearer, 2006).

Vascular changes play a crucial role in the pathogenesis of claw horn disruption lesions, and angiographical as well as histological investigations have shown anatomical changes in blood vessels of bovine hoofs affected with sole ulcer, white line abscess, or claw horn disruption (Singh et al., 1994; Hirschberg and Plendl, 2005). Pulsed-wave (PW) Doppler ultrasonography is a noninvasive method for the detection and evaluation of functional vascular changes in the feet of cattle and horses. This imaging modality has already been used to investigate digital blood flow in the hind feet of nonlame German Holstein cows (Müller et al., 2017) and in the feet of horses with laminitis and septic pododermatitis (Wongaumnuaykul et al., 2006).

The aim of this study was to measure arterial blood flow in the hind feet of German Holstein cows with claw horn disruption lesions (sole ulcer or white line abscess). Qualitative and quantitative blood flow parameters were compared in affected limbs and unaffected contralateral hind limbs in lame cows and in the hind limbs of lame cows and non-lame cows.

\section{MATERIALS AND METHODS}

The study was approved under the guidelines of the Research Animal Act (research permit number 24-9168.21/4/30; A 30/12) by the Regional Council of Saxony, Department of Veterinary Public Health Service and Foodstuff Control, Dresden, Germany.

\section{Animals and Study Design}

A total of 44 German Holstein cows were enrolled in the study. Thirty-three cows that were lame in a hind limb because of claw horn disruption lesions (sole ulcer or white line abscess) of the lateral claw [age: 3.3 to 8.4 (mean 5.3) yr; lactation number: 2 to 6 (mean 3.5); DIM: 21 to 198 (mean 110); BCS: 2.25 to 3.5 (mean 2.8); milk yield: $33.9 \pm 7.2 \mathrm{~kg} / \mathrm{d}$ (mean $\pm \mathrm{SD}$ ); BW: $631 \pm 65 \mathrm{~kg}$; withers height: $142 \pm 3 \mathrm{~cm}$ ] were examined. The hind limb that caused the lameness is referred to as the affected limb and the other hind limb as the contralateral limb. The distribution and severity of claw horn disruption lesions in affected limbs is listed in Table 1.
All of the lame cows had mild to moderate signs of claw horn disruption in both hind feet, which included concavity of the dorsal claw wall $(>2 \mathrm{~mm})$, diverging rings at the claw wall section, widening of the white line, and sole hemorrhages. The coronary band of the affected limb was slightly swollen in 6 of the lame cows and one-third had an increased claw horn temperature at the lateral claw. The selection of lame cows was done due to the examination results of the affected digit. Eleven non-lame cows [age: 3.1 to 3.9 (mean 3.6) yr; second lactation; DIM: 52 to 147 (mean 95); BCS: 2.5 to 3.5 (mean 2.9); milk yield: $35.9 \pm 6.8 \mathrm{~kg} / \mathrm{d}$ (mean $\pm \mathrm{SD}) ; \mathrm{BW}: 609 \pm 80 \mathrm{~kg}$; withers height: $140 \pm 4$ $\mathrm{cm}]$ served as controls. Both hind limbs of the nonlame cows are referred to as control limbs. Seven of the non-lame cows had mild signs of claw horn disruption [concave dorsal wall $(<2 \mathrm{~mm})$, diverging rings at a part of the wall section] but no sole hemorrhages. The study was carried out on a commercial cubicle freestall dairy farm in Saxony, Germany. The cows underwent clinical examination (Dirksen et al., 2012) including lameness scoring (Offinger et al., 2013) by an experienced veterinarian (H. Müller) and claw trimming (Toussaint Raven, 1998) of all feet with the exception of the affected limb of the lame cows. Claw trimming was done by a professional trimmer $1 \mathrm{~d}$ before ultrasonography. Cows with a lameness score of $\mathrm{I}^{+}$to II were classified as mildly lame and cows with a score of $\mathrm{II}^{-}$to III as moderately lame (Offinger et al., 2013; Table 2).

Three days after ultrasonography, the affected hind foot was treated and the claw horn disruption lesions were scored. The terminology used to describe claw horn disruption lesions was based on Espinasse et al. (1984) and Weaver (1994) and the classification of the severity of the lesions was based on Starke et al. (2007). The results of brightness (B)-mode and PW Doppler ultrasonography in affected and contralateral limbs were compared as well as the results in affected and control limbs and in contralateral and control limbs.

\section{Ultrasonography}

A MyLabOne (Esaote Deutschland GmbH, Köln, Germany) ultrasound machine with a linear transducer (linear array $33 \mathrm{~mm}, 10 \mathrm{MHz}$ ) without a standoff pad was used. All cows were examined by an experienced veterinarian (H. Müller). For ultrasonography, the unsedated cows were placed in a standing hoof-trimming chute with a head lock and without a fixation of the limbs. The hair of both hind limbs was clipped from the tarsal region to the coronary band $1 \mathrm{~d}$ before the scan. Immediately before the scan, the clipped lower legs were washed with soap (Baktolin, Bode Chemie 
Table 1. Claw horn disruption lesions in the lateral claw of the affected limb of 33 lame German Holstein cows

\begin{tabular}{lrcc}
\hline & \multicolumn{3}{c}{ Claw horn disruption lesions } \\
\cline { 2 - 4 } Severity & $\begin{array}{c}\text { Sole } \\
\text { ulcer }\end{array}$ & $\begin{array}{c}\text { White line } \\
\text { abscess }\end{array}$ & $\begin{array}{c}\text { Sole ulcer and } \\
\text { white line abscess }\end{array}$ \\
\hline $\begin{array}{l}\text { Superficial lesion } \\
\text { Deep lesion }\end{array}$ & 2 & 3 & - \\
\hline
\end{tabular}

GmbH, Hamburg, Germany), warm water, and a soft brush. Ultrasound gel (Henry Schein GmbH, Berlin, Germany) was applied with a paintbrush. Lame cows had not been treated and the contralateral hind limb was always examined first. In non-lame cows, one hind limb was randomly selected for starting the ultrasonographic examination. The behavior of the cow and the leg position during the examination were recorded as described (Müller et al., 2017). The following scoring system was used for the behavior: $0=$ calm, occasional movements of the hind limbs; $1=$ agitated, frequent movements of the hind limbs; and $2=$ excitable, frequent movements of the hind limbs accompanied by swishing of the tail and turning of the head toward the hind limbs.

The ultrasonographic examination started with Bmode using a protocol described by Heppelmann (2004) for examination of the soft tissues, joints, and bone surfaces, and a protocol by Kofler (1995) for examination of the blood vessels. Pulsed-wave Doppler mode was then used to measure blood flow in a longitudinal section of the interdigital artery in the dorsal pastern region distal to the convergence of the dorsal metatarsal artery III with the dorsal common digital artery III (Nickel et al., 2005). In this region, the interdigital artery runs from the dorsal aspect of the foot in a plantar direction between the digits. The penetration depth was set at 3 $\mathrm{cm}$. When the widest section of the artery was clearly visualized, beam steering $\left(10^{\circ}\right)$ was used to ensure that the angle between blood flow direction and ultrasound waves was less than $60^{\circ}$. The B-mode focus zone was set at the level of the vessel (1.25 or $1.75 \mathrm{~cm}$ image depth), and a low level of gain was used to obtain a slightly dark B-mode picture. Pulsed-wave ultrasonography in the duplex mode was then started while placing the transducer on the artery with as little pressure as possible. The Doppler volume sample cursor was placed in the middle of the vessel and occupied one-half to twothirds of the vessel diameter. The Doppler angle was set in the vessel course. The pulse repetition frequency and level of the zero line were adapted to the blood flow velocity. The PW gain was adjusted to obtain optimum contrast between the Doppler wave form and the background (Hofer, 2009). Self-prepared presets were used to minimize the time required to obtain an image of recordable quality. One image recording a PW Doppler signal of at least $5 \mathrm{~s}$ was stored for each measurement. The whole ultrasonographic examination lasted 36.5 min (mean) per limb. The operator was not blind to limb status when performing the scanning because he was involved in the selection and preparation for ultrasonography on farm.

Table 2. Lameness score according to Offinger et al. (2013)

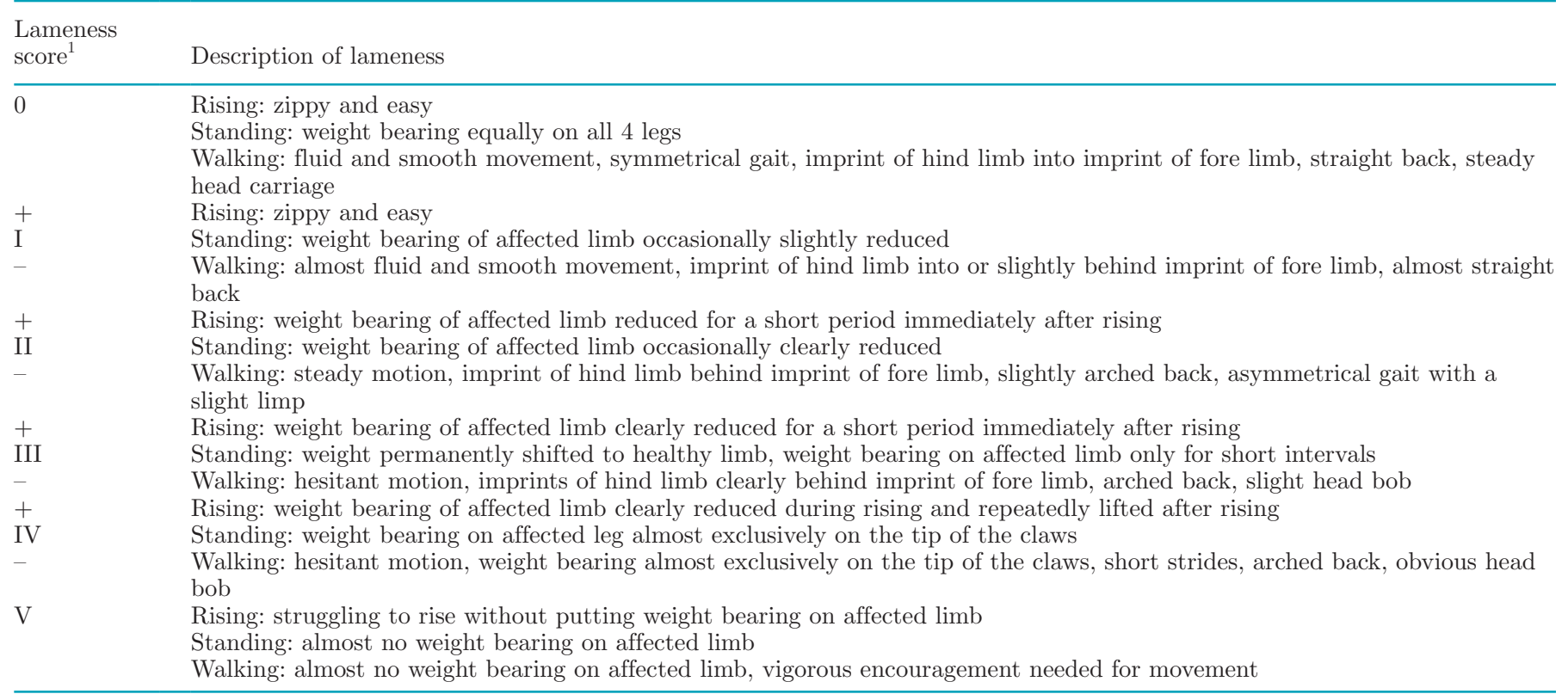

${ }^{1}$ Lameness score: a "+" signifies the tendency of the main score toward the lower score and a "_" toward the higher score. 


\section{Analysis of Pulsed-Wave Doppler Flow Characteristics}

The PW Doppler ultrasound images and data were transferred to the analysis program MyLabDesk (Esaote Deutschland $\mathrm{GmbH}$ ) on a laptop. Three similar cardiac cycles of one measurement series were analyzed by the same examiner ( $\mathrm{H}$. Müller). The analysis of at least 3 cardiac cycles is according to the literature (Wongaumnuaykul et al., 2006; Aguirre et al., 2013). Similarity of cardiac cycles means the same height of the peaks in the waveforms upon visual examination. The profiles of the cardiac cycles were assigned to 1 of 4 different types, and the quantitative variables were measured as described previously (Müller et al., 2017). An analysis of a PW Doppler ultrasound image lasted 5 min per limb.

\section{Statistical Analyses}

Each variable was statistically analyzed by using a linear mixed model with random animal effects. The analyses were based on the following model:

$$
\mathrm{y}_{\mathrm{ijkl}}=\mu+\alpha_{\mathrm{i}}+\beta_{\mathrm{ij}}+\mathrm{a}_{\mathrm{ijk}}+\mathrm{e}_{\mathrm{ijkl}}
$$

where $y_{i j k l}$ is the lth observation on the response variable of the kth animal from the ith limb group ( $i=1$, $2,3)$ and the jth lameness category within the limb group $(j=0,1,2), \mu$ is a common intercept, $\alpha_{i}$ is the fixed effect of the ith limb group, and $\beta_{\mathrm{ij}}$ is the fixed effect of jth lameness category within the limb group. The affected, contralateral, and control limbs form the limb groups. The consideration of more complex covariance structures was examined by comparison with the second-order Akaike information criterion (Hurvich and Tsai, 1989), but did not prove to be necessary. The random animal effect $\mathrm{a}_{\mathrm{ijk}}$ takes into consideration the covariance of repeated observations within animal, and $\mathrm{e}_{\mathrm{ijkl}}$ is the random residual effect.

The residuals were checked for normality using the Shapiro-Wilk test. The variables persistence index
(PI) and blood flow rate (BF) were log-transformed to ensure normal distribution of residuals. Differences between least squares means were analyzed using the Tukey-Kramer test with Kenward-Roger approximation to calculate the degrees of freedom. The least squares means of the PI and BF calculated with log-transformed data were retransformed; these values corresponded to the median of the data before transformation.

The MIXED procedure (SAS, version 9.4, SAS Institute Inc., Cary, NC) was used for estimation of the model parameters. Results were presented as LSM. Differences were considered significant at $P<0.05$, and $0.05<P<0.1$ was considered to reflect a trend toward significance.

\section{RESULTS}

\section{Measurability of Blood Flow in the Interdigital Artery}

The Doppler signal was suitable for analysis in 78 of 88 scanned hind feet (44 cows). The 10 Doppler signals that were not suitable for analysis were obtained from 1 affected and 5 contralateral limbs of 6 lame cows and from both hind limbs of 2 non-lame cows. The B-mode results that accompanied the inadequate PW Doppler signals are listed in Table 3.

\section{Behavior During Ultrasonography}

Eleven of the lame cows $(\mathrm{n}=33)$ were calm, 12 were agitated, and 10 were excited during the examination. Of the non-lame cows $(\mathrm{n}=11), 8$ cows were calm, 2 were agitated, and 1 was excited.

\section{Leg Position During Ultrasonography}

The position of the hind limbs during scanning was mostly normal or forward with the claws loaded evenly. The forward position was most common in affected hind limbs. The positions of the 78 hind limbs from which a useful Doppler signal was obtained are shown in Table 4.

Table 3. Quality of brightness (B)-mode images accompanied by inadequate pulsed-wave Doppler measurements $(\mathrm{n}=10)$ in the hind limbs of 8 (2 control, 6 lame) of 44 German Holstein cows

\begin{tabular}{lccc}
\hline & & Quality \\
\cline { 2 - 4 } Limb group & $\begin{array}{c}\text { Moderate B-mode image } \\
\text { no Doppler signal }\end{array}$ & $\begin{array}{c}\text { Good B-mode image, } \\
\text { no useful Doppler signal }\end{array}$ & $\begin{array}{c}\text { Moderate B-mode image, } \\
\text { no useful Doppler signal }\end{array}$ \\
\hline Affected limb $(\mathrm{n}=1)$ & - & 1 & - \\
Contralateral $\operatorname{limb}(\mathrm{n}=5)$ & 3 & - & 2 \\
Control limb $(\mathrm{n}=4)$ & 3 & - & 1 \\
\hline
\end{tabular}


Table 4. Leg position during pulsed-wave Doppler ultrasonography in the hind limbs of 33 lame ( $\mathrm{n}=60$ limbs) and 11 non-lame ( $\mathrm{n}=18$ limbs) German Holstein cows in which a useful Doppler signal was obtained $(\mathrm{n}=78)$

\begin{tabular}{|c|c|c|c|c|}
\hline \multirow[b]{2}{*}{ Limb group } & \multicolumn{4}{|c|}{ Leg position } \\
\hline & Normal & $\begin{array}{l}\text { Forward, claw } \\
\text { loaded evenly }\end{array}$ & $\begin{array}{l}\text { Forward, claw load } \\
\text { shifted toward toe }\end{array}$ & Backward \\
\hline Affected limb $(\mathrm{n}=32)$ & 13 & 15 & 1 & 3 \\
\hline Contralateral $\operatorname{limb}(\mathrm{n}=28)$ & 19 & 9 & - & - \\
\hline Control limb $(\mathrm{n}=18)$ & 11 & 7 & - & - \\
\hline
\end{tabular}

\section{Results of Brightness-Mode Ultrasonography}

Brightness-mode ultrasonography of the anatomical structures of the foot yielded no abnormalities in non-lame cows and mild abnormalities in 9 lame cows. A mild anechoic effusion in the outer compartment of the lateral digital extensor tendon sheath was seen in both hind feet of one lame cow and in one foot each of 2 other lame cows. In the cows with coronary band swelling, the subcutaneous tissues of the coronary band were increased in width and had a honeycomb appearance. The effects of B-mode ultrasonographic changes on blood flow variables were deemed negligible.

\section{Results of Pulsed-Wave Doppler Ultrasonography}

Qualitative Results. The distribution of the curve types is shown in Table 5 . Curve type 2 was most common overall, and curve types 1 and 2 were more common in the affected and contralateral limbs (90.0\%) than in the control limbs (66.6\%). Respectively, curve type 3 and 4 occurred in the affected and contralateral limb to $10.0 \%$ and in control limbs to $33.4 \%$.

Quantitative Results. The results of the quantitative B-mode and PW Doppler variables for affected, contralateral, and control limbs are shown in Table 6 .

Table 5. Absolute and relative frequencies and their confidence limits $(P=0.95)$ of curve types within the hind limbs of lame and nonlame German Holstein cows in which an analyzable Doppler signal was generated $(\mathrm{n}=78)$

\begin{tabular}{lccc}
\hline & \multicolumn{3}{c}{ Limb group (no./\%), } \\
& \multicolumn{3}{c}{ CI $(P=0.95)$} \\
\cline { 2 - 4 } & Affected & Contralateral & Control \\
Curve type & limb & limb & \\
\hline $1(\mathrm{n}=18)$ & $9 / 28.1$ & $6 / 21.4$ & $3 / 16.7$ \\
& $(15.5 ; 43.9)$ & $(9.8 ; 38.0)$ & $(4.7 ; 37.7)$ \\
$2(\mathrm{n}=48)$ & $20 / 62.5$ & $19 / 67.9$ & $9 / 50.0$ \\
& $(46.4 ; 76.7)$ & $(50.6 ; 82.1)$ & $(29.1 ; 70.9)$ \\
$3(\mathrm{n}=3)$ & $0 / 0.0$ & $0 / 0.0$ & $3 / 16.7$ \\
& $(0 ; 8.9)$ & $(0 ; 10.1)$ & $(4.7 ; 37.7)$ \\
$4(\mathrm{n}=9)$ & $3 / 9.4$ & $3 / 10.7$ & $3 / 16.7$ \\
& $(26.0 ; 22.5)$ & $(3.0 ; 25.4)$ & $(4.7 ; 37.7)$ \\
\hline
\end{tabular}

Vessel diameter (VD), end-diastolic velocity (VENDDIAST), and BF were significantly $(P<0.05)$ greater in affected and contralateral limbs of lame cows than in control limbs, and a trend $(P=0.08)$ was observed for greater maximum time-averaged mean velocity in the affected and contralateral limbs than in control limbs. The pulse rate was significantly $(P<0.05)$ higher in the contralateral limbs than in the affected limbs.

The blood flow variables were also analyzed in relation to the lameness category (mild vs. moderate lameness) of the affected limbs (Table 7). Regardless of lameness category, the vessel diameters in both hind feet of lame cows were significantly larger than the diameter in control limbs, and BF was significantly greater in the affected limbs of the lame cows of both lameness categories than in control limbs. Blood flow rate did not differ between affected and contralateral limbs regardless of lameness category. Numerical increases were observed in maximum systolic velocity, maximum time-averaged mean velocity, and $\mathrm{BF}$ with increasing lameness in the affected and contralateral limbs. The resistance index was numerically higher in control limbs than in limbs of lame cows, and the maximum vessel diameter occurred in the affected limbs of moderately lame cows.

\section{DISCUSSION}

\section{Measurability of Blood Flow in the Interdigital Artery}

In cattle, the dorsal metatarsal artery III has a diameter of approximately $4 \mathrm{~mm}$ (Kofler, 1995) and can be consistently visualized via ultrasonography at the level of the fetlock joint. Ultrasonographic visualization of this artery further distally (interdigital artery) is difficult because the vessel courses between the digits toward the plantar aspect of the foot (Kofler, 1995). In 9 of the 10 hind limbs in which no useful Doppler signal was obtained, the quality of the B-mode image was only moderate. It is likely that suboptimal visualization of the artery by B-mode ultrasonography at this anatomical location combined with the low occlusive pressure exerted by the transducer (to minimize compression of the artery) accounted for the lack of a suitable Doppler 
Table 6. Least squares means $\pm \mathrm{SE}$ of the brightness-mode and pulsed-wave Doppler variables of the interdigital artery in the dorsal pastern region of the hind limbs of lame and non-lame German Holstein cows in which a useful Doppler signal was obtained

\begin{tabular}{lccc}
\hline & \multicolumn{3}{c}{ Limb group } \\
\cline { 2 - 4 } Variable $^{1}$ & Affected limb & Contralateral limb & Control limb \\
\hline VD (mm) & $6.2^{\mathrm{b}} \pm 0.1$ & $6.0^{\mathrm{b}} \pm 0.1$ & $5.2^{\mathrm{a}} \pm 0.2$ \\
VSYST (m/s) & $0.36^{\mathrm{a}} \pm 0.02$ & $0.36^{\mathrm{a}} \pm 0.02$ & $0.29^{\mathrm{a}} \pm 0.03$ \\
VDIAST (m/s) & $0.14^{\mathrm{a}} \pm 0.01$ & $0.14^{\mathrm{a}} \pm 0.01$ & $0.10^{\mathrm{a}} \pm 0.02$ \\
VENDDIAST (m/s) & $0.08^{\mathrm{b}} \pm 0.01$ & $0.09^{\mathrm{b}} \pm 0.01$ & $0.04^{\mathrm{a}} \pm 0.01$ \\
VMEAN (m/s) & $0.17^{\mathrm{a}} \dagger^{\mathrm{a}} \pm 0.01$ & $0.17^{\mathrm{a}} \dagger \pm 0.02$ & $0.11^{\mathrm{a}} \pm 0.02$ \\
RI & $0.84^{\mathrm{a}} \pm 0.04$ & $0.80^{\mathrm{a}} \pm 0.05$ & $0.90^{\mathrm{a}} \pm 0.05$ \\
PI $^{2}$ & $2.13^{\mathrm{a}} \pm 0.35$ & $2.00^{\mathrm{a}} \pm 0.37$ & $2.71^{\mathrm{a}} \pm 0.53$ \\
$\mathrm{BF}^{2}(\mathrm{~mL} / \mathrm{min})$ & $257.02^{\mathrm{b}} \pm 36.04$ & $244.06^{\mathrm{b}} \pm 38.17$ & $119.32^{\mathrm{a}} \pm 20.51$ \\
PR $(1 / \mathrm{min})^{\mathrm{a}}$ & $80^{\mathrm{a}} \pm 2$ & $82^{\mathrm{b}} \pm 2$ & $80^{\mathrm{ab}} \pm 3$ \\
\hline
\end{tabular}

${ }^{\mathrm{a}, \mathrm{b}}$ Within a row, means with different superscripts are different $(P<0.05)$.

${ }^{1}$ Variable: VD = vessel diameter; VSYST $=$ maximum systolic velocity; VDIAST $=$ maximum diastolic velocity; VENDDIAST $=$ end-diastolic velocity; VMEAN = maximum time-averaged mean velocity; $\mathrm{RI}=$ resistance index; $\mathrm{PI}=$ persistence index; $\mathrm{BF}=$ blood flow rate; $\mathrm{PR}=$ pulse frequency.

${ }^{2}$ Median in the original scale, calculated from the LSM estimated in the log-transformed scale.

$\dagger P$-value to control limbs $<0.1$.

signal in some cows (Müller et al., 2017). In a preliminary trial with 10 healthy German Holstein cows, the intraobserver reliability of the measurement technique was evaluated. The intraclass correlation coefficient for the quantitative variables ranged from 0.1 to 0.6 . The data for the measurement of repeatability were recorded 4 times in a 2-d interval. In horse studies the intraclass correlation coefficient was greater, but the studies were performed on anesthetized or trained horses (Raisis et al., 2000a,b; Hoffmann et al., 2001). The major part of Doppler ultrasonography studies at the legs of horses did not state a comment to the intraobserver reliability. In our study the examiner was trained on more than 30 cows by experts from human and veterinary medicine in the performance and assessment of Doppler ultrasonography. The further improvement of reliability is a methodical challenge for the examined variables. We expect that the intraclass correlation coefficient is greater with repeated measurement within one day. Overall, however, the measuring site used in the present study appears well suited for PW Doppler ultrasonography in dairy cows.

Table 7. Least squares means $\pm \mathrm{SE}$ of the brightness-mode and pulsed-wave Doppler variables of the interdigital artery in the dorsal pastern region of the hind limbs of cows of 2 lameness categories (mild and moderate) and non-lame German Holstein cows in which a useful Doppler signal was obtained

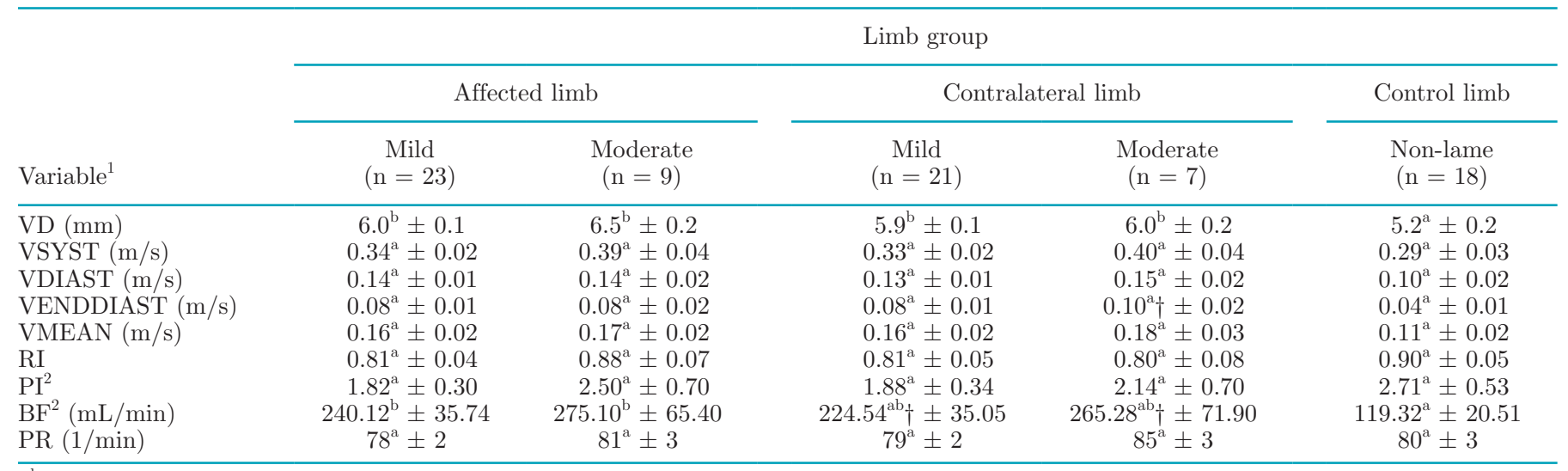

${ }^{\mathrm{a}, \mathrm{b}}$ Within a row, means with different superscripts are different $(P<0.05)$.

${ }^{1}$ Variable: VD = vessel diameter; VSYST $=$ maximum systolic velocity; VDIAST $=$ maximum diastolic velocity; VENDDIAST $=$ end-diastolic velocity; VMEAN = maximum time-averaged mean velocity; $\mathrm{RI}=$ resistance index; $\mathrm{PI}=$ persistence index; $\mathrm{BF}=\mathrm{blood}$ flow rate; $\mathrm{PR}=\mathrm{pulse}$ frequency.

${ }^{2}$ Median in the original scale, calculated from the LSM estimated in the log-transformed scale.

$\dagger P$-value to control limbs $<0.1$. 


\section{Comparison of Affected and Control Limbs- Qualitative Parameters}

Curve types 1 and 2 occurred predominantly in affected limbs of lame cows (90.0\%) compared with control limbs (66.6\%). These curve types occur when perfusion is increased because of inflammation or when there is an increase in activity (Hofer, 2009), and they are characterized by a higher diastolic blood flow velocity. Hence, the inflammation caused by lesions of claw horn disruption in the affected limbs is one reason for the observed distribution of curve types. Furthermore, in our study, an increase in activity was recorded as agitation of the cows during scanning; agitated cows moved their hind limbs more frequently than calm cows. It was shown that an increase in hind limb movement is associated with a higher frequency of weight shifting in the hind feet (Chapinal and Tucker, 2012; Nechanitzky et al., 2016). More lame cows than non-lame cows were categorized as agitated in the present study and it is therefore likely that the greater proportion of curve types 1 and 2 in affected limbs is also related to frequent weight shifting in the hind feet. By comparison, curve types 3 and 4 were more prevalent in control limbs of nonlame cows (33.4\%), which stood still more often during the examination than lame cows. Therefore, the feet of non-lame cows had increased vascular resistance and hence a decrease in diastolic blood flow velocity and an increase in RI (Müller et al., 2017). The distribution of curve types of control limbs was the same obtained in a PW Doppler ultrasonography study in non-lame dairy cows (Müller et al., 2017). The authors suspected that the variety of curve types were caused by variability in weight bearing. So-called resistance blood flow profiles similar to curve types 3 and 4 of the present study have been described in sound horses, whereas horses with septic pododermatitis or laminitis had mainly low- or non-resistance blood flow profiles similar to curve types 1 and 2 seen in the present study (Wongaumnuaykul et al., 2006). Other authors observed low-resistance blood flow profiles also in sound horses and medium- to highresistance blood flow profiles in horses with laminitis (Aguirre et al., 2013). The discrepancy in the results may have been due to differences in the stage of laminitis or in weight bearing during scanning. To restrict the influence of weight bearing, the limbs had to be fixed in our study. But this procedure has a high influence on digital blood flow. In a study with sound horses, there was no curve type with a reverse diastolic blood flow, whether the limb was standing on the ground (weight bearing) or lifted up (non-weight bearing; Hoffmann et al., 2001). The structure of the curve types was similar; each had a curve type with one systolic peak followed by one or more diastolic peaks and an end-diastolic plateau (Hoffmann et al., 2001). Hence, in that study, the sound horses had low-resistance curve types. Based on the described literature about horses, we estimated that inflammation in the toe had greater influence on qualitative blood flow parameters than did the weight shifting or weight bearing of the limbs. That is why we decided against fixation of the limb during ultrasonography in this study.

\section{Comparison of Affected and Control Limbs- Quantitative Parameters}

Lame cows had significantly greater VD, BF, and VENDDIAST than non-lame cows regardless of whether the affected or the contralateral limb was compared. The blood flow variables of the PW Doppler parameters in the non-lame cows were similar to those reported previously (Müller et al., 2017), but we were unable to find values for blood flow variables for lame cows in the current literature. Lame horses with septic pododermatitis or laminitis had significantly greater blood flow velocities, BF, and VD and a lower PI than sound horses (Wongaumnuaykul et al., 2006). Blood flow velocities measured in sound horses were similar to those measured in the control cows of the present study, whereas the blood flow velocities measured in lame horses (Wongaumnuaykul et al., 2006; Aguirre et al., 2013) were much greater than those obtained in our group of lame cows. In both referenced horse studies (Wongaumnuaykul et al., 2006; Aguirre et al., 2013), an increase in surface temperature of the hoof capsule was an inclusion criterion; however, only onethird of the lame cows in our study had increased claw horn temperatures. Therefore, the reason that blood flow velocities were lower in lame cows compared with lame horses was most likely the fewer cases of acute claw horn disruption lesions (sole ulcer and white line abscess) in lame cows. Lameness category had a moderate, nonsignificant effect on blood flow velocities and $\mathrm{BF}$, which tended to be greater in moderately lame cows than in mildly lame cows. A possible reason for the nonsignificance is the small number of moderately lame cows. The maximum mean vessel diameter and the maximum $\mathrm{BF}$ values occurred in the affected limbs of moderately lame cows.

\section{Comparison of Affected and Contralateral Limbs- Qualitative and Quantitative Parameters}

Because of the claw horn lesions, we expected a higher proportion of curve types 1 and 2 in affected limbs compared with the contralateral limbs but there was no difference. Likewise, affected and contralateral limbs did not differ with respect to blood flow variables 
regardless of lameness category. A significant difference existed in the PR. However, the mean difference was 2 heartbeat per minute. The pulse rate measured with Doppler ultrasound could be different because the measurement in both hind limbs was not simultaneous. As described in the Materials and Methods section, in lame cows the contralateral hind limb was always examined first. The anxiety of the lame cows, which lead to an important increase in pulse rate, did not exist during the measurement of both hind limbs.

Blood flow variables are affected by the weight carried by the limbs, but this was not measured during scanning. Instead, we recorded behavior in terms of limb movements and leg position. Lameness was mild to moderate in the present study, and it has been shown that lame cows shift weight between limbs more often than non-lame cows (Pastell et al., 2006; Rushen et al., 2007; Kujala et al., 2008). In humans it is well known that in a standing position, hydrostatic pressure in limbs is high, peripheral vascular resistance increases, and BF decreases (Krishnan et al., 2011). Shifting weight from limb to limb causes a decrease in peripheral vascular resistance immediately after lifting of a limb. This is presumably what occurred in the lame cows during scanning and may explain the higher proportion of curve types 1 and 2 in affected and contralateral limbs than in control limbs as mentioned above. The trend toward higher blood flow velocities in moderately lame cows compared with mildly lame cows may have been related to more frequent move- ments of the limbs in the former group (Nechanitzky et al., 2016) or fewer cases of acute claw horn disruption lesions. Blood flow measurements in the legs of humans showed reactive hyperemia caused by arterial vasodilation after a short ischemic period (Krishnan et al., 2011), and it is possible that this same event occurred in the contralateral limbs of the cows, leading to an increase in BF. An increase in the severity of lameness leads to more pronounced differences in weight bearing between paired limbs in cows (Pastell and Kujala, 2007; Pastell et al., 2010; Nechanitzky et al., 2016) and reduces the frequency of weight shifting (Pastell and Kujala, 2007). Thus, in severely lame cows, the contralateral limb carried excessive weight for longer periods of time, the vascular resistance increased and curve types 3 and 4 became more common. Theoretically this can be expected to result in persistent hypoperfusion of the pododerm; however, arteriovenous anastomoses in the bovine toe play a role in mitigating intra-ungular pressure during weight bearing (Greenough, 2007). It is also conceivable that curve types 1 and 2 develop when the arteriovenous anastomoses open as a result of increased peripheral vascular resistance. This concept is supported by the predominance of curve types 3 and 4 in calm non-lame cows. The proposed relationship between weight bearing, inflammation of the corium, and mitigating effects of arteriovenous anastomoses is illustrated in Figure 1.

The lack of a significant difference between blood flow variables in affected and contralateral limbs may

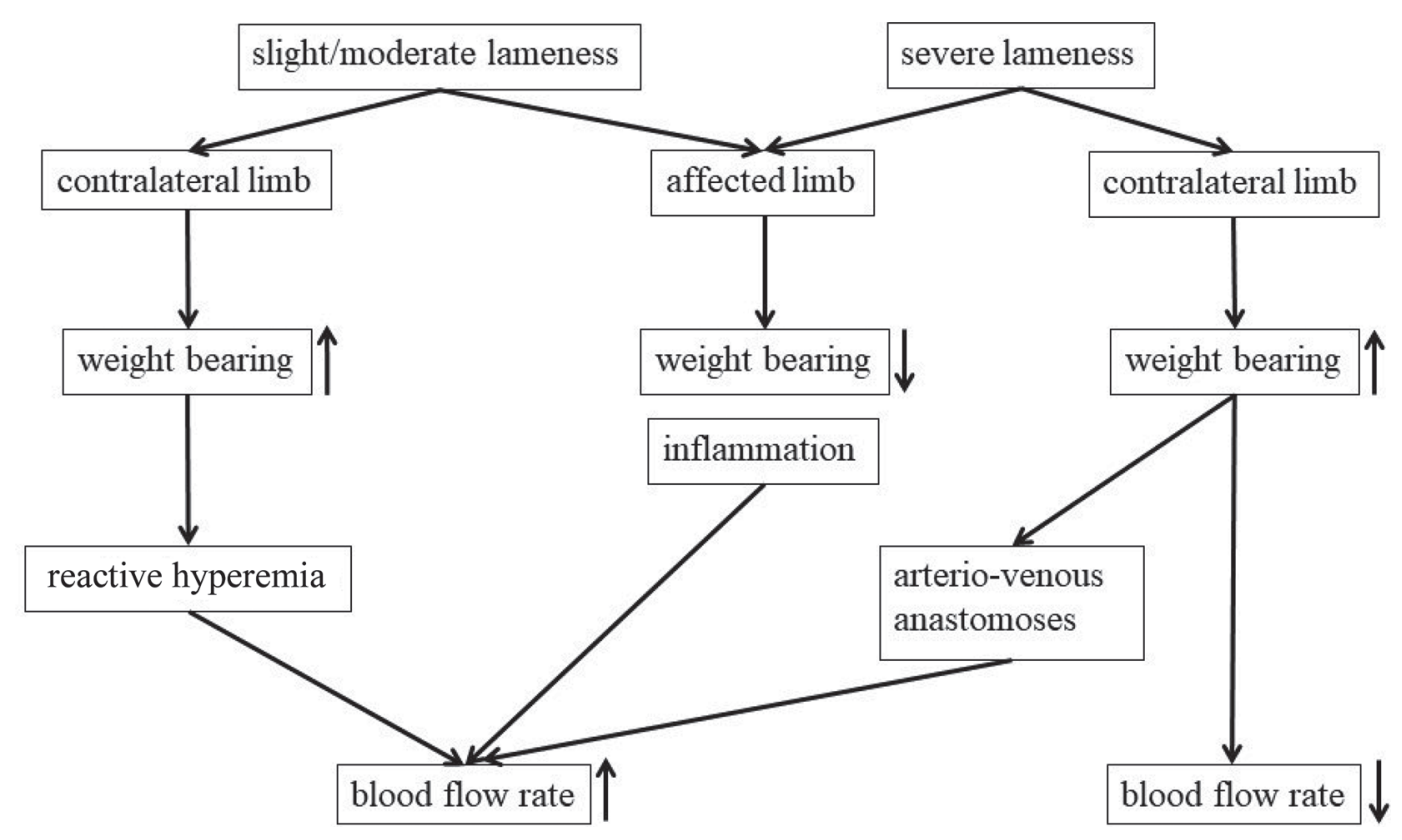

Figure 1. Proposed relationship of weight bearing, inflammation, and arterio-venous anastomoses on the blood flow rate in the affected and contralateral hind limbs of German Holstein cows according to the lameness score. 
have been because local alterations of claw horn disruption detected during claw trimming were similar in the paired limbs. The alterations were mild to moderate in lame cows and absent or mild in non-lame cows. Postmortem angiographic studies of feet from cows with claw horn disruption showed that the dorsal digital artery was dilated and tortuous in its course distal to the middle phalanx and there was constriction of more distal arteries running from the distal phalanx toward the pododerm as well as dilatation of anastomoses in the heel area (Maclean, 1970; Boosman et al., 1989). In the present study, the diameter of the interdigital artery was significantly larger in lame cows than in non-lame cows, but it did not differ between affected and contralateral limbs. This may have been attributable to claw horn disruption; constriction of arteries at the distal phalanx did not cause an increase in peripheral vascular resistance because of the arteriovenous anastomoses and thus curve types 3 and 4 were not seen. However, as a result of the blood flow through the anastomoses, parts of the pododerm suffered hypoperfusion (Boosman et al., 1989) even though blood flow was increased proximally.

Other reasons are possible for the similarities in blood flow variables and distribution of curve types in affected and contralateral limbs. Lame cows with a sole ulcer have significantly higher gene expression of IL-1 $\alpha$, IL-1 $\beta$, IL-8, and IL-10 in leukocytes compared with cows without sole ulcers (O'Driscoll et al., 2015). Furthermore, there is an upregulation of IL-2, matrix metalloproteinase 13 , chemokine $\mathrm{C}-\mathrm{C}$ motif receptor 5 , and IL-10 in lame cows compared with non-lame cows (Almeida et al., 2007). Interleukin-1 stimulates nitric oxide-synthetase in smooth muscle cells and causes vasodilatation in humans (Schini et al., 1994; Sprague and Khalil, 2009). However, whether blood flow variables in the contralateral limbs were affected by leukocyte profiles and gene expression is not known.

\section{CONCLUSIONS}

Several differences in qualitative and quantitative PW Doppler variables were detected in the hind limbs of lame and non-lame cows. Most lame cows with claw horn disruption lesions caused by superficial to deep sole ulcer or white line abscess had blood flow profiles 1 and 2 in the interdigital artery, and VD, BF, and VENDDIAST were greater in lame cows. These changes reflect inflammatory changes of the pododerm. An increase in lameness score was accompanied by a numerical increase in the blood flow variables VD, $\mathrm{BF}$, and maximum systolic velocity. The degree of difference found between sound horses and horses with pododermatitis as expected before realization of the study was not seen in the comparison of affected and control limbs in cattle. Causes for this observation are the weight-bearing and the stages of inflammation. The lack of difference in blood flow variables between affected and contralateral limbs was most likely due to irregular weight-bearing associated with shifting weight between limbs and to the vascular changes associated with claw horn disruption. The anatomical location used for scanning the interdigital artery is well suited for the detection of changes in digital blood flow in lame cows. Our findings suggest that inflammation of the pododerm is not the only factor affecting blood flow in the digits of lame dairy cows.

\section{ACKNOWLEDGMENTS}

This work was generously supported by grants from the H. Wilhelm Schaumann Foundation (Hamburg, Germany), Esaote Biomedica Germany Ltd. (Cologne, Germany), Boehringer Ingelheim Pharma Ltd. \& Co. KG (Cologne, Germany), and Selectavet Dr. Otto Fischer Ltd. (Weyarn-Holzolling, Germany). The authors thank the farm management of Wirtschaftshof Sachsenland Röhrsdorf/Wittgensdorf e.G. (Chemnitz, Germany), Kathrin Nechanitzky, Helena Fieseler, Anne Kretschmar, Tanja Gärtner, and Halina Masur (Clinic for Ruminants and Swine, University of Leipzig, Germany), and the trimmers Andreas Busch, Silvio Wiesner, and Andre Wissel from the Genossenschaft Klauenpfleger e.G. Sachsen (Lohmen, Germany) for their help and support. Special thanks go to Stefan Nüske from the Lehr- und Versuchsgut Oberschleißheim, LMU Munich, Germany.

\section{REFERENCES}

Aguirre, C. N., J. Talavera, and M. J. Fernandez del Palacio. 2013. Usefulness of Doppler ultrasonography to assess digital vascular dynamics in horses with systemic inflammatory response syndrome or laminitis. J. Am. Vet. Med. Assoc. 243:1756-1761. https: //doi.org/10.2460/javma.243.12.1756.

Almeida, P. E., P. S. D. Weber, J. L. Burton, R. J. Tempelman, J. P. Steibel, and A. J. Zanella. 2007. Gene expression profiling of peripheral mononuclear cells in lame dairy cows with foot lesions. Vet. Immunol. Immunopathol. 120:234-245. https://doi.org/10 .1016/j.vetimm.2007.06.028.

Becker, J., A. Steiner, S. Kohler, A. Koller-Bähler, M. Wüthrich, and M. Reist. 2014. Lameness and foot lesions in Swiss dairy cows: I. Prevalence. Schweiz. Arch. Tierheilkd. 156:71-78. https://doi.org/ 10.1024/0036-7281/a000553.

Beer, G., M. Alsaaod, A. Starke, G. Schuepbach-Regula, H. Müller, P. Kohler, and A. Steiner. 2016. Use of extended characteristics of locomotion and feeding behavior for automated identification of lame dairy cows. PLoS One. https://doi.org/10.1371/journal pone.0155796.

Bell, N. J. 2015. Evidence-based claw trimming for dairy cattle. Vet. Rec. 177:220-221. https://doi.org/10.1136/vr.h4591.

Boosman, R., F. Nemeth, E. Gruys, and A. Klarenbeek. 1989. Arteriographical and pathological changes in chronic laminitis in dairy cattle. Vet. Q. 11:144-155. 
Chapinal, N., and C. B. Tucker. 2012. Validation of an automated method to count steps while cows stand on a weighing platform and its application as a measure to detect lameness. J. Dairy Sci. 95:6523-6528. https://doi.org/10.3168/jds.2012-5742.

DeFrain, J. M., M. T. Socha, and D. J. Tomlinson. 2013. Analysis of foot health records from 17 confinement dairies. J. Dairy Sci. 96:7329-7339. https://doi.org/10.3168/jds.2012-6017.

De Vries, M., E. A. M. Bokkers, C. G. van Reenen, B. Engel, G. van Schaik, T. Dijkstra, and I. J. M. de Boer. 2015. Housing and management factors associated with indicators of dairy cattle welfare. Prev. Vet. Med. 118:80-92. https://doi.org/10.1016/j.prevetmed .2014.11.016

Dirksen, G., H.-D. Gründer, and M. Stöber. 2012. Die klinische Untersuchung des Rindes. 4th ed. Enke, Stuttgart, Germany.

Espinasse, J., M. Savey and C. M. Thorley. 1984. Colour Atlas on Disorders of Cattle and Sheep Digit. Point Veterinaire and Societe Francaise de Buiatrie, France.

Gernand, E., D. A. Döhne, and S. König. 2013. Genetic background of claw disorders in the course of lactation and their relationship with type traits. J. Anim. Breed. Genet. 130:435-444. https://doi .org/10.1111/jbg.12046.

Gonzalez-Sangues, A., and J. K. Shearer. 2002. The biomechanics of weight bearing and its significance with lameness. Page 117-121 in Proc. 12th International Symposium on Lameness in Ruminants, Orlando, FL. University of Florida, Gainesville.

Greenough, P. 2007. The microvasculature supplying the dermis (pododerm, corium, or quick). Pages 25-28 in Bovine Laminitis and Lameness: A Hands on Approach. 1st ed. P. Greenough, ed. Saunders Elsevier, USA.

Hendry, K. A. K., A. J. MacCallum, C. H. Knight, and C. J. Wilde. 1997. Laminitis in the dairy cow: A cell biological approach. J. Dairy Res. 64:475-486.

Heppelmann, M. 2004. Eitrige Klauengelenksentzündung beim Rind: Vergleich des Heilungsverlaufes nach Klauengelenksresektion mit plantarem Zugang und nach hoher Klauenamputation. Inaugural Dissertation, Hannover, Germany.

Hirschberg, R. M., and J. Plendl. 2005. Pododermal angiogenesis and angioadaptation in the bovine claw. Microsc. Res. Tech. 66:145155. https://doi.org/10.1002/jemt.20154.

Hoblet, K. H., and W. Weiss. 2001. Metabolic hoof horn disease: Claw horn disruption. Vet. Clin. North Am. Food Anim. Pract. 17:111127

Hofer, M. 2009. FKDS-Trainer-Ein Arbeitsbuch für den Einstieg in die Farbkodierte Duplexsonographie und Echokardiographie. 3rd ed. Didamed, Berlin, Germany.

Hoffmann, K. L., A. K. W. Wood, K. A. Griffiths, D. L. Evans, R. W. Gill, and A. C. Kirby. 2001. Doppler sonographic measurements of arterial blood flow and their repeatability in the equine foot during weight bearing and non-weight bearing. Res. Vet. Sci. 70:199-203.

Holzhauer, M., C. Hardenberg, and C. J. M. Bartels. 2008. Herd and cow-level prevalence of sole ulcers in the Netherlands and associated-risk factors. Prev. Vet. Med. 85:125-135. https://doi.org/10 .1016/j.prevetmed.2008.01.004

Hultgren, J., and C. Bergsten. 2001. Effects of a rubber-slatted flooring system on cleanliness and foot health in tied dairy cows. Prev. Vet. Med. 52:75-89.

Hurvich, C. M., and C. L. Tsai. 1989. Regression and time series model selection in small samples. Biometrika 76:297-397.

Kofler, J. 1995. Darstellung und Durchmesserbestimmung der Arterien und Venen am Hinterfuß des Rindes mittels B-Mode. J. Vet. Med. A Physiol. Pathol. Clin. Med. 42:253-266.

Krishnan, A., E. B. Lucassen, C. Hogeman, C. Blaha, and U. A. Leuenberger. 2011. Effects of limb posture on reactive hyperemia. Eur. J. Appl. Physiol. 111:1415-1420. https://doi.org/10.1007/ s00421-010-1769-z.

Kujala, M., M. Pastell, and T. Soveri. 2008. Use of force sensors to detect and analyse lameness in dairy cows. Vet. Rec. 162:365-368. https://doi.org/10.1136/vr.162.12.365.

Laven, R. A., and K. R. Lawrence. 2006. An evaluation of the seasonality of veterinary treatments for lameness in UK dairy cattle.
J. Dairy Sci. 89:3858-3865. https://doi.org/10.3168/jds.S0022 -0302(06)72428-6.

Maclean, C. W. 1970. A post-mortem x-ray study of laminitis in barley beef animals. Vet. Rec. 86:457-462.

Manske, T., J. Hultgren, and C. Bergsten. 2002. Prevalence and interrelationships of hoof lesions and lameness in Swedish dairy cows. Prev. Vet. Med. 54:247-263.

Müller, H., M. Heinrich, N. Mielenz, S. Reese, A. Steiner, and A. Starke. 2017. Evaluation of arterial digital blood flow using Doppler ultrasonography in healthy dairy cows. BMC Vet. Res. https: //doi.org/10.1186/s12917-017-1090-8.

Mülling, C. K. W., H. H. Bragulla, S. Reese, K.-D. Budras, and W. Steinberg. 1999. How structures in bovine hoof epidermis are influenced by nutritional factors. Anat. Histol. Embryol. 28:103-108.

Nechanitzky, K., A. Starke, B. Vidondo, H. Müller, M. Reckardt, K. Friedli, and A. Steiner. 2016. Analysis of behavioral changes in dairy cows associated with claw horn lesions. J. Dairy Sci. 99:2904-2914. https://doi.org/10.3168/jds.2015-10109.

Newsome, R., M. J. Green, N. J. Bell, M. G. G. Chagunda, C. S. Mason, C. S. Rutland, C. J. Sturrock, H. R. Whay, and J. N. Huxley. 2016. Linking bone development on the caudal aspect of the distal phalanx with lameness during life. J. Dairy Sci. 99:4512-4525. https://doi.org/10.3168/jds.2015-10202.

Nickel, R., A. Schummer, and E. Seiferle. 2005. Lehrbuch der Anatomie der Haustiere - Band III Kreislaufsystem, Haut und Hautorgane. 4th ed. Parey, Germany.

O'Driscoll, K., M. McCabe, and B. Earley. 2015. Differences in leukocyte profile, gene expression, and metabolite status of dairy cows with or without sole ulcers. J. Dairy Sci. 98:1685-1695. https://doi .org/10.3168/jds.2014-8199.

Offinger, J., S. Herdtweck, A. Rizk, A. Starke, M. Heppelmann, H. Meyer, S. Janßen, M. Beyerbach, and J. Rehage. 2013. Postoperative analgesic efficacy of meloxicam in lame dairy cows undergoing resection of the distal interphalangeal joint. J. Dairy Sci. 96:866876. https://doi.org/10.3168/jds.2011-4930.

Pastell, M., L. Hänninen, A. M. de Passilé, and J. Rushen. 2010. Measures of weight distribution of dairy cows to detect lameness and the presence of hoof lesions. J. Dairy Sci. 93:954-960. https://doi .org/10.3168/jds.2009-2385.

Pastell, M., H. Takko, H. Gröhn, M. Hautala, V. Poikalainen, J. Praks, I. Veermäe, M. Kujala, and J. Ahokas. 2006. Assessing cows' welfare: Weighing the cow in a milking robot. Biosyst. Eng. 93:81-87. https://doi.org/10.1016/j.biosystemseng.2005.09.009.

Pastell, M. E., and M. Kujala. 2007. A probabilistic neural network model for lameness detection. J. Dairy Sci. 90:2283-2292. https:// doi.org/10.3168/jds.2006-267.

Proudfoot, K. L., D. M. Weary, and M. A. G. Keyserlingk. 2010. Behavior during transition differs for cows diagnosed with claw horn lesions in mid lactation. J. Dairy Sci. 93:3970-3978. https://doi .org/10.3168/jds.2009-2767.

Raisis, A. L., L. E. Young, H. Meire, P. M. Taylor, K. Walsh, and P. Lekeux. 2000a. Variability of Doppler ultrasound measurements of hindlimb blood flow in conscious horses. Equine Vet. J. 32:125132. https://doi.org/10.2746/042516400777591561.

Raisis, A. L., L. E. Young, H. Meire, K. Walsh, P. M. Taylor, and P. Lekeux. 2000b. Repeatability of Doppler ultrasound measurements of hindlimb blood flow in halothane anaesthetized horses. Equine Vet. J. 32:239-246. https://doi.org/10.2746/042516400776563662.

Rüegsegger, F., E. Muggli, and K. Nuss. 2015. Asymmetry in digit length in cows with sole ulcer. A post-mortem study of slaughter cows. Tierarztl Prax Ausg G Grosstiere Nutztiere 43:137-143. https://doi.org/10.15653/TPG-140590.

Rushen, J., E. Pombourcq, and A. M. de Passilé. 2007. Validation of two measures of lameness in dairy cows. Appl. Anim. Behav. Sci. 106:173-177. https://doi.org/10.1016/j.applanim.2006.07.001.

Schini, V. B., R. Busse, and P. M. Vanhoutte. 1994. Inducible nitric oxide synthase in vascular smooth muscle. Arzneimittelforschung 44:432-435.

Shearer, J. K., S. R. van Amstel, and B. W. Brodersen. 2012. Clinical diagnosis of foot and leg lameness in cattle. Vet. Clin. North Am. 
Food Anim. Pract. 28:535-556. https://doi.org/10.1016/j.cvfa 2012.07.003.

Singh, S. S., W. R. Ward, and R. D. Murray. 1994. An angiographic evaluation of vascular changes in sole lesions in the hooves of cattle. Br. Vet. J. 150:41-52.

Sogstad, A. M., T. Fjeldaas, O. Østerås, and K. Plym Forshell. 2005. Prevalence of claw lesions in Norwegian dairy cattle housed in tie stalls and free stalls. Prev. Vet. Med. 70:191-209. https://doi.org/ 10.1016/j.prevetmed.2005.03.005.

Solano, L., H. W. Barkema, E. A. Pajor, S. Mason, S. J. LeBlanc, J. C. Zaffino Heyerhoff, C. G. R. Nash, D. B. Haley, E. Vasseur, D. Pellerin, J. Rushen, A. M. de Passilé, and K. Orsel. 2015. Prevalence of lameness and associated risk factors in Canadian HolsteinFriesian cows housed in freestall barns. J. Dairy Sci. 98:6978-6991. https://doi.org/10.3168/jds.2015-9652.

Sprague, A. H., and R. A. Khalil. 2009. Inflammatory cytokines in vascular dysfunction and vascular disease. Biochem. Pharmacol. 78:539-552. https://doi.org/10.1016/j.bcp.2009.04.029.

Starke, A., M. Heppelmann, M. Beyersbach, and J. Rehage. 2007. Septic arthritis of the distal interphalangeal joint in cattle: Comparison of digital amputation and joint resection by solar approach. Vet. Surg. 36:350-359. https://doi.org/10.1111/j.1532-950X.2007 $.00257 . x$.
Tarlton, J. F., and A. J. F. Webster. 2002. A biochemical and biomechanical basis for the pathogenesis of claw horn lesions. Page 395-398 in Proc. 12th International Symposium on Lameness in Ruminants, Orlando, FL. University of Florida, Gainesville.

Toholj, B., M. Cincovic, M. Stevancevic, J. Spasojevic, V. Ivetic, and A. Potkonjak. 2014. Evaluation of ultrasonography for measuring solar soft tissue thickness as a predictor of sole ulcer formation in Holstein-Friesian dairy cows. Vet. J. 199:290-294. https://doi.org/ 10.1016/j.tvjl.2013.11.005.

Toussaint Raven, E. 1998. Klauenpflege beim Rind: über die Entstehung und Vorbeuge von Sohlengeschwüren. 1st ed. Brouwer Uithof, the Netherlands.

van Amstel, S. R., and J. K. Shearer. 2006. Review of pododermatitis circumscripta (ulceration of the sole) in dairy cows. J. Vet. Intern. Med. 20:805-811.

Weaver, A. D. 1994. International terminology of digital disease. Pages 25-28 in Proc. 8th International Symposium on Disorders of the Ruminants Digit, Banff, Canada.

Wongaumnuaykul, S., C. Siedler, H. Schobesberger, and C. Stanek. 2006. Doppler sonographic evaluation of the digital blood flow in horses with laminitis or septic pododermatitis. Vet. Radiol. Ultrasound 47:199-205. https://doi.org/10.1111/j.1740-8261.2006 .00128 . 